\title{
Fertility Levels among Women of Stone Crushing Industry from Matigara Block of Darjeeling District, West Bengal
}

\author{
Subir Biswas and Debopama Bagchi \\ Department of Anthropology, University of North Bengal, Raja Rammohunpur, \\ Darjeeling 734 013, West Bengal, India \\ E-mail: gargisubir@gmail.com
}

KEYWORDS Stone Crusher. Fertility. Occupational Health. Demography. North Bengal.

\begin{abstract}
Fertility refers to the actual reproductive performance of a woman or group of women, which is biological in nature but numerous social cultural factors also affect the phenomenon. The occupation may be categorized as such a factor which affects fertility directly or indirectly due to their unique work environment and occupational hazards._In this article an attempt has been made to explore the fertility levels and its correlates of women from stone crushing industry keeping in mind the probable occupational environment, socio-cultural attributes and hazards due to their occupational exposures. Data has been collected from women of stone crushing industry from Balason colony, Matigara block, Darjeeling district of West Bengal, after household survey, interview and observation. The analysis of fertility is carried out in period perspective and data on age is estimated by recall method with cross check. Fertility rates and ratios are estimated following standard formula. The overall fertility rates of the group are somewhat higher than state or nation. The sex ratio is also higher favouring females. The high fertility may be attributed to lower age at marriage, lower age at first delivery, low literacy rate as well as higher infant mortality beside their occupational hazards.
\end{abstract}

\section{INTRODUCTION}

Fertility is a biological phenomenon, though numerous social-cultural factors supposed to influence fertility level of a woman or a group of women. Human fertility refers to the reproductive capacity of a woman during her entire reproductive period. The term fertility is generally used to connote the actual reproductive performance of a woman or the number of children a woman has or the average number of children for a group of women (Srinivasan 1998). Fertility is the reproductive behaviour of women and all the events and actions that are directly involved in the process by which they give birth to a child. However, male fertility (or infertility) indirectly affects the reproductive performance of his wife.

Davis and Blake (1956) had suggested a model having three variables of fertility viz. intercourse variables, conception variables and gestation variables. Freedman (1975) had modified the model and examined how fertility has been influenced by social and economic structure of a population along with environment and mortality. Another model of fertility was developed by Hill et al. (1959) consists of three variables viz., antecedent variables, intervening variables and consequent variables. Easterlin (1975) had presented a model of fertility as economic model of fertility. Sandhu (1996) in her study of Punjab had developed another model of fertility operationalized as under demographic variables, family action, general values and so on. Bhattacharya and Halder (2003) had described the rural fertility model with examples from rural West Bengal. Mahadevan and Sumangla (1987) examined the links between social development, cultural changes and decline fertility of Kerala population. Visaria and Visaria (1995) described how fertility behaviour of women determined by number of social and biological factors.

The correlation between working status of women and fertility was examined by different scholars. Akadli-Ergocmen (1997), Moon (1987), Dex et al. (1998), Saxena and Aoun (1997), AlRiyami et al. (2004), Winegarden (1984), Gendell and Kneiter (1970), and Chaudhury (1996) had identified that fertility of working women is lower than their non-working counterpart of all states. This may be because of social values as when women are confined only to household jobs, they are considered suitable only for producing good number of children. In such situation, fertility is higher compared to where the women are expected to participate in all walks of life, along with men.

However, Singh (1988) observed a different situation and concluded that when women's occupation is not accompanied by education, it 
can not lowering the fertility level, therefore, women's work status is not automatically related to lower fertility (Hong 1983); it may be related only among educated women (Morcors 1974). Again, women engaged in work outside the home had fewer children than both those who earned by working at home and non-working women (Nanda and Surender 1997; Chaudhury 1996).

Female work status has a link with family planning acceptance (Sundar 1990), child loss (Nanda and Surender 1997) and occupational psychological stress (Sheiner et al. 2003). Instead of above risks the working women of rural India are at a high risk of developing various occupational and environmental diseases (Fulekar 2000), which adversely affect fertility.

The women from stone crushing industry by their own specific situation due to working environment may have some sort of health hazards as well as fertility level due to working condition and social-cultural situation of the same. Biswas and Bhattacharjee (2007) in a study among stone crushers of same block have identified higher proportion of child death and foetal loss due to poverty, ill health and lack of health awareness.

The present paper is an attempt to examine the fertility level of women from stone crushing industry. The study proposes to analyze fertility in terms of the micro-variables. The relationships of different variables with fertility are also studied. The project was designed to study different variables such as age at marriage, age at first delivery, age at menarche, menopause, mortality, educational level, family planning etc, all of which have some sort of influences on fertility.

\section{MATERIALS AND METHODS}

The research work is based on a sample from women of stone crushing industry of Balason Colony under Tarijot, Matigara Block, Darjeeling district. The colony is situated at the side of Balason river, nearby Matigara and is easily accessible by road from Silliguri to Naxalbari. Most of the families are engaged on stone crushing industry by collecting stones from Balason riverbed and crushing the same. The area is mainly consists of Rajbansi and Nepali communities; among them the Rajbansis were selected for the present study.

Rajbansis, an autochthonous and dominant ethnic group of North Bengal, according to 1991 census constituted 17.7 percent of the total
Scheduled Caste population of West Bengal (having 2839481 souls) with 40.7 percent literacy rate (54.4 percent for male and 26 percent for female). As per Risley (1891) they are "a Dravidian caste of Northern Bengal, originally Kochh, but now claiming to be an outlying branch of Kshatriyas". The other view of origin is that they are a Mongoloid race that entered Bengal from the East by way of Brahmaputra valley (Dash 1947). Sanyal (1965) wrote, "At a time when Rajbansis of North Bengal were going out of the Hindu fold and embracing other faiths, Babu Panchanan Burman of Rangpur raised the claim that the northern Rajbansis were Kshatriyas and advanced the above arguments....The Rajbansis began to take the sacred Thread and declared themselves as Kshatriyas". However, after the introduction of official list of Scheduled Castes (1936) they asked for and finally find themselves in the Scheduled Caste list of Bengal coined by the British followed by Article 341 of Indian Constitution and Order of 1950 and 1956. Mukhopadhyay (1999) stated "at one situation they asked for Kshatriya status in the regional caste structure and later being a Scheduled Caste/ $\mathrm{OBC}$ are enjoying preferential treatment for last several decades. Recently they are striving for tribal status painstakingly retracing their forgotten ethnic affinity with tribal Koches."

Hundred families from stone crushing industry were taken for the study by random sampling, comprising 472 populations. An extensive fieldwork was done during 21.02.05 to 20.08.05. Out of 472 persons of both sexes, 122 mothers were identified.

The data were mainly field based i.e. primary data, though in some cases primary data were supplemented by secondary data. The primary data sources include household questionnaire survey and interview. Beside these, the study demands to include observation instead of above. The analysis of fertility is carried out in a period perspective i.e. the events occur in a given period are studied. To calculate the fertility rates and ratios of different groups and the population as a whole, the following calculations were done using standard formula (Srinivasan 1998). In case of population as a whole, the Age Specific Fertility Rates (ASFR's) were calculated as the number of births per 1000 women of a given age per year. While Total Fertility Rate was obtained by using following formulae i.e. TFR $=($ Sum of ASFR's X class interval)/1000. General Fertility Rate (GFR) was calculated as 'the number of births that occur 
in a year per 1000 women of child bearing age (1549 years)'. Crude Birth Rate (CBR) was calculated as total registered live birth to the total population, also in same specific year, also multiplied by 1000 (Barcley 1958)

The present age, age at menarche, menopause, marriage and first delivery in case of women have been collected using recall method and cross examined with their age, age of child, age of near relatives or after important events of the region.

Data were analyzed both qualitatively as well as quantitatively. For statistical inferences of the data, mean and standard deviation were calculated beside simple percentages. To understand the relationship between two variables the correlation analysis was done following standard formula. (Madrigal 1998). Statistical calculation of data was also conducted by using PAST, Version 1.34 (Hammer et al. 2001).

\section{RESULTS AND DISCUSSION}

In our reference area, the economy is based on different types of labour work. Most of the families are engaged with stone crushing. They have to work about 9-10 hours per day. However, some differences may have seen in case of female due to their household work. They work for 7-8 hours per day. Sometime they have to work during third trimester of pregnancy, therefore, pregnancy wastages are the common matter. There is no fixed working hours, people do hard work as much as they can do, to earn more money. Most of the families work under thikadars with a weekly payment. There is no variation of wages for age and sex; it depends on the quantity of stone they used to crush. However, during rainy season, it is difficult to work as water level of the river rises, and stone collection becomes difficult.

Table 1 is the distribution of the population according to age and sex. Female are found to be more in number than male when total population according to age and sex is taken into consideration. Sex ratio (1017.09) is higher favouring female compared to nation, state or district. The abrupt decline of female after 30-34 years may be attributed to higher death rate of these groups. However, overall population pyramid reveals an expending stage, but not in continuation; this may be because of small number of data that represents the population.

Table 2 reveals that overall fertility rates of the population exhibit a high fertility whether it is
Table 1: Age-sex structure of the population

\begin{tabular}{lrrrr}
\hline $\begin{array}{l}\text { Age Group } \\
\text { (in year) }\end{array}$ & Male & Female & Total & $\begin{array}{c}\text { Sex } \\
\text { ratio }\end{array}$ \\
\hline $0-4$ & 29 & 37 & 66 & 1275.86 \\
$5-9$ & 38 & 33 & 71 & 868.42 \\
$10-14$ & 27 & 30 & 57 & 1111.11 \\
$15-19$ & 13 & 29 & 42 & 2230.76 \\
$20-24$ & 22 & 23 & 45 & 1045.45 \\
$25-29$ & 24 & 27 & 51 & 1125.00 \\
$30-34$ & 20 & 18 & 38 & 900.00 \\
$35-39$ & 18 & 7 & 25 & 388.88 \\
$40-44$ & 14 & 7 & 21 & 500.00 \\
$45-49$ & 9 & 6 & 15 & 666.66 \\
$50-54$ & 5 & 7 & 12 & 1400.00 \\
$55-59$ & 4 & 3 & 7 & 750.00 \\
$60-64$ & 3 & 6 & 9 & 2000.00 \\
$65-69$ & 3 & 3 & 6 & 1000.00 \\
$70+$ & 5 & 2 & 7 & 400.00 \\
\hline Total & 234 & 238 & 472 & 1017.09 \\
\hline
\end{tabular}

TFR (4.193), CFR (38.13) or GFR (130.43). In case of ASFR's it reaches its peak at the age of 20-24 years (391.30), after that it decreases sharply. In $25-29$ years age group it is 142.85 , in $30-34$ it is 111.11 and in 35-49 it is 55.55; after that it reaches to zero.

Table 2: Fertility Levels of the population

\begin{tabular}{|c|c|c|}
\hline & Fertility Measures & Value \\
\hline 1 & Crude Birth Rate (CBR) & 38.13 \\
\hline 2 & General Fertility Rate (GFR) & 130.43 \\
\hline 3 & Total Fertility Rate (TFR) & 4.193 \\
\hline $4 \mathrm{a}$ & Age Specific Fertility Rate (15-19 years) & 137.93 \\
\hline $4 \mathrm{~b}$ & Age Specific Fertility Rate (20-24 years) & 391.30 \\
\hline $4 \mathrm{c}$ & Age Specific Fertility Rate (25-29 years) & 142.85 \\
\hline $4 d$ & Age Specific Fertility Rate (30-34 years) & 111.11 \\
\hline $4 \mathrm{e}$ & Age Specific Fertility Rate (35-39 years) & 55.55 \\
\hline
\end{tabular}

Table 3 exhibits some Biological and SocioCultural attributes of the population which may have a direct relationship with fertility. These are age at menarche (mean 14.26 years \pm SD 0.88), age at menopause (mean 47.35 years \pm SD 3.29), age at marriage (mean 15.84 years \pm SD 2.09) and age at first delivery (mean 17.13 years \pm SD 2.29).

Table $3 \mathrm{~A}$ reveals that there might be a negative correlation between age at menarche and fertility. The lower is the age at menarche, the higher is the fertility level; with some exception may be due to small sample size. The same negative correlation is found between fertility and age at marriage or age of mother at first delivery. The higher is the age at marriage or age at first delivery, the lower is the fertility level (Table 3C and 3D). However Table 3B states a positive correlation between age at menopause and fertility; the fertility level elevated with increasing age at 
Table 3: Some biological and socio-cultural attributes

\begin{tabular}{llrl}
\hline $\begin{array}{l}\text { S. } \\
\text { No. }\end{array}$ & $\begin{array}{c}\text { Biological /Socio-cultural } \\
\text { attributes }\end{array}$ & & Mean $\pm S D$ \\
\hline 1 & Mean Age at Menarche & $14.26 \pm 0.88$ years \\
2 & Mean Age at Menopause & $47.35 \pm 3.29$ years \\
3 & Mean Age at $1^{\text {st }}$ Marriage & $15.84 \pm 2.09$ years \\
4 & Mean Age at First delivery & $17.13 \pm 2.29$ years
\end{tabular}

Table 3A: Age at menarche and children born per women

\begin{tabular}{lccc}
\hline $\begin{array}{l}\text { Age at } \\
\text { menarche } \\
\text { in year) }\end{array}$ & $\begin{array}{c}\text { No. of } \\
\text { women } \\
(\%)\end{array}$ & $\begin{array}{c}\text { Total No } \\
\text { of children } \\
\text { born }\end{array}$ & $\begin{array}{c}\text { Children born } \\
\text { per women } \\
(C B W)\end{array}$ \\
\hline $11-12$ & $1(0.7)$ & 4 & 4.00 \\
$12-13$ & $12(8.57)$ & 49 & 4.08 \\
$13-14$ & $32(22.86)$ & 112 & 3.50 \\
$14-15$ & $69(49.28)$ & 159 & 2.30 \\
$15-16$ & $26(18.57)$ & 59 & 2.23 \\
\hline Total & $140(100)$ & 383 & 2.73 \\
\hline
\end{tabular}

Table 3B: Age at menopause and children born per women

\begin{tabular}{llcc}
\hline $\begin{array}{l}\text { Age at } \\
\begin{array}{l}\text { menopause } \\
\text { (in year) }\end{array}\end{array}$ & $\begin{array}{c}\text { No. of } \\
\text { women } \\
(\%)\end{array}$ & $\begin{array}{c}\text { Total No } \\
\text { of children } \\
\text { Born }\end{array}$ & $\begin{array}{c}\text { Children born } \\
\text { per women } \\
(\text { CBW })\end{array}$ \\
\hline $35-40$ & $1(3.70)$ & 3 & 3 \\
$40-45$ & $5(18.52)$ & 17 & 3.4 \\
$45-50$ & $11(40.74)$ & 40 & 3.6 \\
$50-55$ & $10(37.04)$ & 41 & 4.1 \\
$55-60$ & - & - & - \\
\hline Total & $27(100)$ & 101 & 3.74 \\
\hline
\end{tabular}

Table 3C: Age at marriage and children born per women

\begin{tabular}{llcc}
\hline $\begin{array}{l}\text { Age at } \\
\text { marriage } \\
\text { (in year) }\end{array}$ & $\begin{array}{c}\text { No. of } \\
\text { women } \\
(\%)\end{array}$ & $\begin{array}{c}\text { Total No } \\
\text { of children } \\
\text { Born }\end{array}$ & $\begin{array}{c}\text { Children born } \\
\text { per women } \\
(\text { CBW) }\end{array}$ \\
\hline $11-13$ & $5(3.88)$ & 31 & 6.2 \\
$13-15$ & $46(35.66)$ & 164 & 3.56 \\
$15-17$ & $42(32.56)$ & 101 & 2.40 \\
$17-19$ & $2519.38)$ & 58 & 2.32 \\
$19-21$ & $9(6.97)$ & 23 & 2.55 \\
$21+$ & $2(1.55)$ & 6 & 3.0 \\
\hline Total & $129(100)$ & 383 & 2.96 \\
\hline
\end{tabular}

Table 3D: Age of mother at first delivery and children born per women

\begin{tabular}{llcc}
\hline $\begin{array}{l}\text { Age at } \\
\text { first delivery } \\
\text { (in year) }\end{array}$ & $\begin{array}{c}\text { No. of } \\
\text { women } \\
(\%)\end{array}$ & $\begin{array}{c}\text { Total No } \\
\text { of children } \\
\text { Born }\end{array}$ & $\begin{array}{c}\text { Children born } \\
\text { per women } \\
(\text { CBW })\end{array}$ \\
\hline $12-14$ & $1(0.82)$ & 4 & 4.0 \\
$14-16$ & $47(38.52)$ & 145 & 3.08 \\
$16-18$ & $38(31.15)$ & 131 & 3.44 \\
$18-20$ & $19(15.57)$ & 56 & 2.94 \\
$20-22$ & $14(11.48)$ & 39 & 2.78 \\
$22-24$ & $1(0.82)$ & 3 & 3.0 \\
$24+$ & $2(1.64)$ & 5 & 2.5 \\
\hline Total & $122(100)$ & 383 & 3.14 \\
\hline
\end{tabular}

Table 3E: Education and children born per women

\begin{tabular}{lrrrr}
\hline Type & $\begin{array}{c}\text { No. of } \\
\text { family }\end{array}$ & $\begin{array}{c}\text { No. of } \\
\text { mother }\end{array}$ & $\begin{array}{c}\text { Total } \\
\text { no. of } \\
\text { children }\end{array}$ \\
\hline Father only literate & 13 & 13 & 35 & 2.69 \\
Mother only literate & 6 & 6 & 21 & 3.50 \\
Both are literate & 9 & 9 & 25 & 2.77 \\
Both are illiterate & 94 & 94 & 302 & 3.21 \\
\hline
\end{tabular}

Table 3F: Age at marriage and mortality

\begin{tabular}{|c|c|c|c|c|c|c|}
\hline \multirow{2}{*}{$\begin{array}{l}\text { Age at } \\
\text { marri- } \\
\text { age } \\
\text { (in year) }\end{array}$} & \multirow{2}{*}{$\begin{array}{l}\text { No. of } \\
\text { moth- } \\
\text { er } \\
(\%)\end{array}$} & \multicolumn{3}{|c|}{ Child mortality } & \multirow{2}{*}{$\begin{array}{c}\text { Total } \\
\text { morta } \\
\text { lity }\end{array}$} & \multirow{2}{*}{$\begin{array}{c}\text { Morta- } \\
\text { lity/ } \\
\text { women }\end{array}$} \\
\hline & & $\begin{array}{c}\text { Decea } \\
\text { sed }\end{array}$ & $\begin{array}{c}\text { Abor- } \\
\text { tion }\end{array}$ & $\begin{array}{l}\text { Still- } \\
\text { Birth }\end{array}$ & & \\
\hline $11-13$ & 5 & 4 & 15 & 2 & 21 & 4.2 \\
\hline $13-15$ & 46 & 10 & 41 & 17 & 68 & 1.47 \\
\hline $15-17$ & 42 & 8 & 35 & 4 & 47 & 1.11 \\
\hline $17-19$ & 25 & 3 & 23 & 6 & 32 & 1.28 \\
\hline $19-21$ & 9 & 2 & 3 & - & 5 & 1.8 \\
\hline $21+$ & 2 & - & 1 & - & 1 & 0.5 \\
\hline Total & 129 & 27 & 118 & 29 & 174 & 1.34 \\
\hline
\end{tabular}

Table 3G: Family Planning method adoption and C B W

\begin{tabular}{lccc}
\hline $\begin{array}{l}\text { Family } \\
\text { planning } \\
\text { method }\end{array}$ & $\begin{array}{c}\text { No. of } \\
\text { couple (\%) }\end{array}$ & $\begin{array}{c}\text { Total no. } \\
\text { of children }\end{array}$ & CBW \\
\hline Adopted & $53(41.09 \%)$ & 148 & 2.79 \\
Not adopted & $76(58.91 \%)$ & 235 & 3.09 \\
\hline Total & $129(100 \%)$ & 383 & 2.96 \\
\hline
\end{tabular}

menopause. The education also has its effect on reducing fertility; the literacy level of father may have greater influence than mother (Table 3E). Table $3 \mathrm{~F}$ suggests a negative correlation between age at marriage and mortality of the population, it indicate child mortality decreases with advancement of age at marriage. The last table of this series (Table 3G) exhibit that $41 \%$ of the couple of this population has adopted family planning measures; though among them only $33.96 \%$ are confined to male and remaining $66.04 \%$ attributed to female.

The Crude Birth Rate of the population (38.13) is higher than rural West Bengal (22.4), rural India (26.4) or combined rural urban data of state or nation as well (20.3 and 24.8, respectively). General Fertility Rate (GFR) of women from stone crushing industry is again much higher (130.43) than the GFR of Rural area of West Bengal (81.7) or India (103.5) or as a whole combined rural urban data of both (73.5 and 95.3, respectively). The same has been evident for Total Fertility Rate (TFR) of the population (4.193), which is much higher than rural West Bengal (2.5), rural India (3.2) or even combined figure of rural urban data (2.3 and 3.0, respectively). 
Let us compare the Age Specific Fertility Rates (ASFR's) of the population with India and West Bengal. In case of 15 to 19 years, the Age Specific Fertility Rate (137.93) is much higher than India (46.1) and West Bengal (66.0). For age group 20 to 24 years of women from stone crushing industry, the ASFR is also higher (391.30) than India (214.4) and West Bengal (183.0). However in case of 25-29 years age group the ASFR of the population (142.85) is higher than State (112.9) but lower than Nation (171.3). In case of 30 to 34 or 35 to 39 , it is (111.11 and 55.55 respectively) again higher than State (56.4 and 21.6, respectively) or Nation (90.6 and 44.1, respectively). However, after that it sharply declines to zero, though for State or Nation it continues up to 45-49 years of age.

The Total Fertility Rate of illiterate population is 3.94 which is again higher than West Bengal (2.9) but somewhat lower than rural India (4.1) or combined figure of India (4.0) as a whole. The women from stone crushing industry those are literate but below class-X, the TFR is 3.36 which is higher than rural India (2.0) and West Bengal (1.4) as well.

Within the limit because of small sized sample, the result manifestly fulfills the purposes stated as objectives of the study.

The group exhibits some uniqueness starting from age-sex structure. The sex ratio of the population (1017.09) suggests proportionate high female representation in almost all age groups, which is simply reverse compared to block (Matigara: 902), district (Darjeeling: 943), state (West Bengal: 934) or nation (India: 933), as per census of India 2001. The high sex ratio in favour of female is because of social and economic value of women in the society, as women (or even girl child) also earn by way of stone crushing and collecting as well. However they prefer boys in case of first pregnancy, this may be because of underlying mind set in favour of boys for the sake of social rituals. Inspite of the above, the sex ratio increases, which again suggest the relatively better health care of the female, compared to their surrounding blocks. However, we can't say that girls have better health care compared to boys, as boys are biologically more delicate than girls. Again, the life span of stone crusher women compared to their men counterpart is less; therefore, the right top portion (female side) of population pyramid is thinner than left. This sharp decline of women is found after 35-39 years age group.
As per fertility concern the fertility rates of the population remain higher compared to state or national level. This may be another cause to higher sex ratio, as the higher is the event the greater is the chance of having the ratio of $1: 1$. The Total Fertility Rate (4.193), Crude Birth Rate (38.13) as well as General Fertility Rate (130.43) of the group is also higher compared to others. The higher fertility rates may be because of desire for more and more children, as greater number of children indicates greater number of workforce for a family. Even the truly childhood period is very short. The child above nine years has to assist their parents for stone crushing.

The higher fertility is not influenced by education so much as state or nation. This is because of less number of literate women and most of the women belonging to literate groups are actually literate but without any formal education or access over primary education only. The age specific fertility rates have a distinctive elevation up to 20-24 age groups, when it attains its peak (391.30) then decline sharply, and reach at zero before the age of 40 years, compared to 45-49 years age group in case of West Bengal or India. This is mostly because of adoption of different family planning methods after that stage.

The higher fertility is also attributed to higher reproductive span. It starts from menarche (mean 14.26 years \pm SD 0.88 ) and continues up to menopause (mean 47.35 years \pm SD 3.29). However, functionally it starts from age at marriage (mean 15.84 years \pm SD 2.09) and shortly after that, they became fertile after their first delivery (mean age 17.13 years \pm SD 2.29).

As per factor responsible for fertility concern the followings factors influence the fertility positively or negatively. A strong negative correlation in relation to fertility $(\mathrm{CBW})$ is found with age at menarche $(-0.923)$ age of mother at first delivery (-0.842) and age at marriage (-0.69), whereas a strong positive correlation is found between fertility (CBW) and age at menopause $(+0.98)$.

Another correlates of fertility is mortality. As a whole the Crude Death Rate of the group (12.71) is comparatively higher than Rural India (8.7 as per SRS 2003) or Rural West Bengal (6.8 as per SRS 2003). The Infant Mortality Rate (111.11) is also higher than average value of rural India (66 as per SRS 2003) and rural West Bengal (48 as per SRS 2003). So, this may be another reason of high fertility of the group. As in such society where death rates are high there is a tendency to have 
more and more number of children because of high mortality.

The study instead of its limitation because of small sized data reveals high fertility rates of women from Stone Crushing industry of the region. The high fertility rates may be attributed to lower age at marriage, lower age at first delivery, illiteracy as well as due to higher mortality rates compared to others.

\section{ACKNOWLEDGEMENT}

The author wish to acknowledge Centre for Women's Studies, North Bengal University for financial assistance to D. Bagchi.

\section{REFERENCES}

Akadli-Ergocmen BA 1997. An Overview of Women's Status and Fertility in Turkey. In: Cosio-Zavala (Ed.): Women and Families: Evolution of the Status of Women as Factor and Consequence of Changes in Family Economics. Paris: CICRED, pp.79-105

Al Riyami A, Afifi M, Mabry RM 2004. Women's Anatomy, Education and Employment in Oman and their Influence on Contraceptive Use. Health Matters, 12 (23): 144-154.

Barclay GW 1958. Techniques of Population Analysis. New York: Willey.

Bhattacharya RN, Halder SK 2003. Determinants of Rural Fertility in West Bengal: A Micro-level Evidence. Indian J Soc Dev, 3(2): 241-264.

Biswas SK, Bhattacharjee S 2007. Health Situation among the Stone Crushers of Balason River Bed in Siliguri, West Bengal, India. In: Buddhadeb Chaudhuri and Sumita Chaudhuri (Eds.). Health, Environment Development and other Essayes: Anthropological Perspectives. New Delhi: Inter-India Publications, pp.182-202.

Chaudhury RH 1996. Factors Affecting Variations in Fertility by States of India: A Preliminary Investigation. Asia-Pacific Population Journal, 11(2): 59-68.

Dash AJ 1947. Bengal District Gazetteers-Darjeeling. Alipore: Bengal Govt. Press.

Davis K, Blake J 1956. Social Structure and Fertility: An Analytical Framework. Economic Development and Cultural Change, 4: 211-35.

Dex S, Heather J, Macran S, Mc Culloch A 1998. Women's Employment, Traditions around Child Bearing. Oxford Bulletin of Economics and Statistic, 60(1): 79-98.

Easterlin RA 1975. An Economic Framework for Fertility Analysis. Studies on Family Planning, 6(3): 54-63.

Freedman R 1975. The Sociology of Human Fertility: An Annotated Bibliography. New York: Irvington Publishers.

Fulekar MH 2000. Occupational Health of Women. Asian-Pacific Newsletter, 3: 69-73.

Gendell M, Kneiter PC 1970. Fertility and Economic Activity of Women in Guatemala City, 1964. Demography, 7(3): 273-286.
Hammer O, Harper DAT, Ryan PD 2005. Palaeontological Statistics Software Package for Education and Data Analysis. From <http://folk.uio.no/ ohammer/past> (Retrieved November 1 2005)

Hill R, Stycos SM, Back KW 1959. The Family and Population Control. New Haven: College and University Press Publishers.

Hong S 1983. Marital Fertility Differential by Women Working Status in Korea. Bull Eugen Soc, 15(2): 55-60.

India, Govt. of 1991. Census of India. New Delhi: Registrar General \& Census Commissioner of India.

India, Govt. of 2001. Census of India. New Delhi: Registrar General \& Census Commissioner of India.

India, Govt. of 2007. Census of India: Figures at a Glance, India 2003. From < http://www.censusindia.gov.in/ vital_statistics/Vital_Rates/Vital_rates.aspx > (Retrieved November 1 2007)

Madrigal L 1998. Statistics for Anthropology. Cambridge: Cambridge University Press.

Mahadevan K, Sumangala M 1987. Social Development, Cultural Change and Fertility Decline. New Delhi: Sage Publication India Pvt.

Moon C 1987. Subjective Economic Status, Sex Role Attitude, Fertility and Mother's Work. Ingu Pogon Nonjip, 7 (1): 177-196.

Morcors W 1974. Employment of Women and Fertility: A Field Study in EI-Waily District, Cairo, Egypt. Popul Fam Plann Rev, 7(1): 21-29.

Mukhopadhyay RS 1999. Contradiction and Change in Social Identity of the Rajbansis. J Indian Anthrop Soc, 34: 133-138.

Nanda S, Surender S 1997. Female Work Status and its Relationship with Fertility and Child Loss in Orissa. The Journal of Family Welfare, 43(3): 34-37.

Risley HH 1891. The Tribes and Castes of Bengal, Vol-II. Calcutta: Bengal Secretariat Press.

Sandhu J 1996. Sociology of Fertility. Jaipur: Rawat Publications.

Sanyal CC 1965. The Rajbansis of North Bengal. Calcutta: The Asiatic Society.

Saxena PC, Aoun HY 1997. Women's Education, Economic Activity and Fertility: Relationship Reexamined. Al-Abhath, 45: 25-39.

Sheiner E, Sheiner EK, Potashnik G, Garel R, ShohamVardi I 2003. The Relationship between Occupational Psychological Stress and Female Fertility. Occupational Medicine, 53: 265-269.

Singh M 1988. Age at Marriage and Fertility: With Special Reference to India. Asian Profile, 16 (1): 59-66.

Srinivasan K 1998. Basic Demographic Techniques and Application. New Delhi: Sage Publication India.

Sundar R 1990. The Status of Women and Family Planning Acceptance: Some Field Results. The Journal of Family Welfare, 36: 60-68.

Visaria L, Visaria P 1995. India's Population Transition. Population Bulletin, 50(3): 1-51.

West Bengal, Govt. of Health and Family Welfare, Dept. of 2007. Health Statistics (2007). From < http:// www.wbhealth.gov.in/Statistics.asp?pass_file_id $=25$ $>$ (Retrieved November 1 2007)

Winegarden CR 1984. Women's Fertility, Market Work and Marital Status: A Test of the New Household Economic with International Data. Economica, 51: 447- 456 